\title{
E-GOVERNMENT IN POLAND - SELECTED ISSUES
}

\author{
MaLwina PoPioŁeK \\ malwinapopiolek@gmail.com \\ Opole University, Poland
}

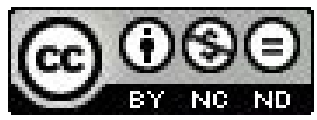

\begin{abstract}
Nowadays, the development of e-government is one of the biggest challenges for many countries around the world. Levels of e-government are very important indicators of information society structure advancement in the country. Development of e-government often faces many different obstacles. This article focuses on issues relating to some problems associated with the development of e-government in Poland.

Key words: e-government, Internet, information society, new media, E-government Development Index, computerization in Poland, ICT, e-government development

\section{INTRODUCTION}

We are witnessing a dynamic growth of the role and importance of information and communication technology (ICT). They are present in all aspects of our daily life. They are also becoming important in politics and the economy. We are moving towards an information society and knowledge-based economy. As theorists note, the development of the information society is inevitable. Backwardness in this matter may result in negative consequences in many aspects of life and functioning of a state (Masłyk, 2010, p. 22).

To keep up with the pace of technological change, many countries are implementing various modernizations. They are preparing plans and strategies with the aim of progressing in the development of the information society. The development of e-government is often one of the priorities in this regard.

This article presents selected issues of e-government development in Poland. It is a review of the most important Polish research and evaluations of the level of e-government. It also presents some problems and considerations in the light of previous research and study.
\end{abstract}

\section{THE IDEA AND ROLE OF E-GOVERNMENT}

Since the 1990s, when the use of network began to spread, ICT has been entering slowly into all areas of the economy. This has given rise to the new global economy, called the new economy or the e-economy. In this modern reality, the flow of information, capital and labor, determines the character of contemporary capitalism. It has changed the financial markets, trade, services and business (Doktorowicz, 2005, p. 45). All of these adaptation changes were inevitable. If the European Union wants to be competitive in the international market,it must keep up with technological development. For that reason the development of the information society structures is 
not only a choice, but a necessity. There is a new quality in the economy, based on increasing development of new technologies. According to experts, they need to be standardized and harmonized across the world (Papińska-Kacperek, 2008, pp. 409410). To remain competitive in the world market, all countries need to take care of the development of the information society structures. Countries within the EU have to accept a number of provisions related to the development of the information society. A very important element here is e-government (Doktorowicz, 2005, p. 159). Figure 1 presents the division within the new economy, and the position of e-government.

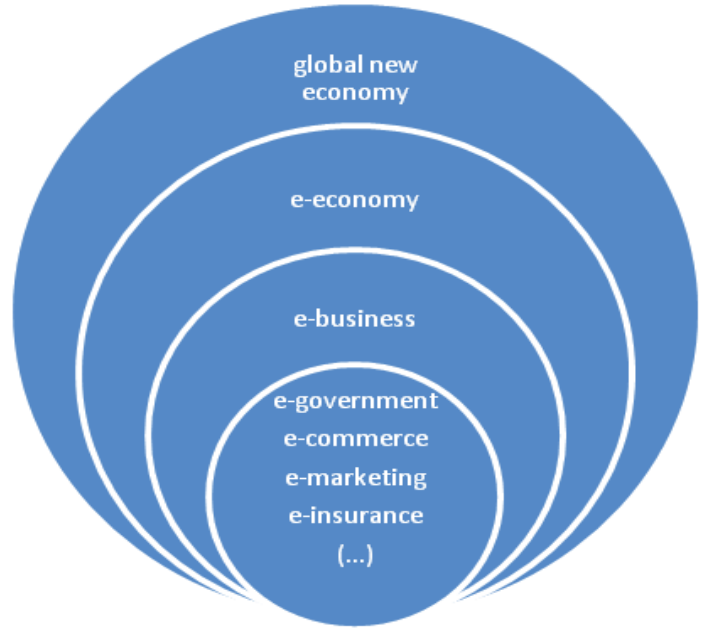

Figure 1. The divisions within the new economy

Source: J. Papińska-Kacperek, 2008, p. 410.

As we can see, e-government is a part of electronic economy, and more specifically, electronic business. In the area of e-business we can distinguish i.a. e-government, e-commerce, e-marketing, e-insurance, e-payment, e-finance, e-procurement, etc. (Papińska-Kacperek, 2008, p. 410).

According to Manuel Castells, one of the greatest theoreticians of the information society, a mature economic globalization can proceed only on the basis of modern ICT. The richest countries governments and international organizations, e.g. WTO, IMF, World Bank have a big impact to the intensification of these processes, (Castells, 2007, pp. 135-138).

Electronic government can be defined variously. One of the simplest and most common understandings of the e-government concept focuses on the use of information and communication technologies (ICT) to facilitate the operation of government (www.eadministracja.pl). In that case e-government is a new way of dealing with any official matters, more easily and more accessibly, both for citizens and officials. However, taking into account more aspects, the concept of e-government may also have other dimensions.

Generally, according to experts, we can talk about e-government in both the narrow and wide context (Grodzka, 2009, p. 58). The first is associated almost 
exclusively with the entry of new technologies into the sphere of government. In that case, the main goal of e-government is to provide electronic access to public services for citizens. This approach is typical for America or Japan. The countries of European Union or the United Nations represent a rather broader view. Their approach relates more to the transformation and a new perception of administration caused by popularization of e-government. The new way of governing is admittedly designed to facilitate the process of dealing with any official matters, to save time and money, to enable the citizen to cope with every case without leaving home. But it is also associated with the involvement of citizens in the democratic processes. They become active players in the processes of administration. The public sector is becoming more transparent and accessible. The aim is to make administrative processes more efficient, make them more convenient for citizens and also reduce the workload of officials (Grodzka, 2009, p. 58).

The flow of public information in e-government can take different directions. We can distinguish three main channels of information flow (Kasprzyk, 2011, pp. 343-344):

- government to citizens (G2C) - e.g. ID and passport service, tax assembling, registration of business, job search and registration of unemployed, health registration, etc.;

- government to business (G2B) - e.g. income tax, procurement service, etc.;

- government to government (G2G) - e.g. interactions between departments, authorities and other governmental organizations;

The foundation of digital government is to enable citizens to settle their matters entirely via the Internet. This model of government has many advantages, such as (Kasprzyk, pp. 346-347):

- saving time and administrative costs;

- the possibility to settle matters anytime and practically everywhere;

- the facility for people with disabilities (especially physical disabilities);

- unlimited e-office activity; etc.

In fact, an opportunity to settle the matter completely is not that obvious. According to the European Commission we can distinguish four levels of public service development (Grodzka, pp. 61-62):

- on-line information - an ability to acquire the most important information about a matter, from the web site of the office;

- one direction interaction - an ability to find information and download the forms needed to settle the matter;

- both directions interaction - ability to find information, fill out forms on-line, and then send the completed forms to the office via the Internet;

- transaction - complete operation of the whole process of settling the case, finding information, downloading the forms, filling out and sending forms via the Internet, submitting an electronic signature, option to pay the fees and acquire an official document applied for;

As we can see the level of advancement of e-services can vary. Generally the aim is to get the fourth level of advancement - the complete transaction. 


\section{IMPLEMENTATION OF E-GOVERNMENT IN POLAND}

Before the implementation of e-government in Poland started, it had been very important to extensively computerize the offices. It was necessary to develop ICT infrastructure. As we can see in the following graph, a few years ago,the problem of digital exclusion in Poland was very serious (Batorski, 2011, pp. 299-300).

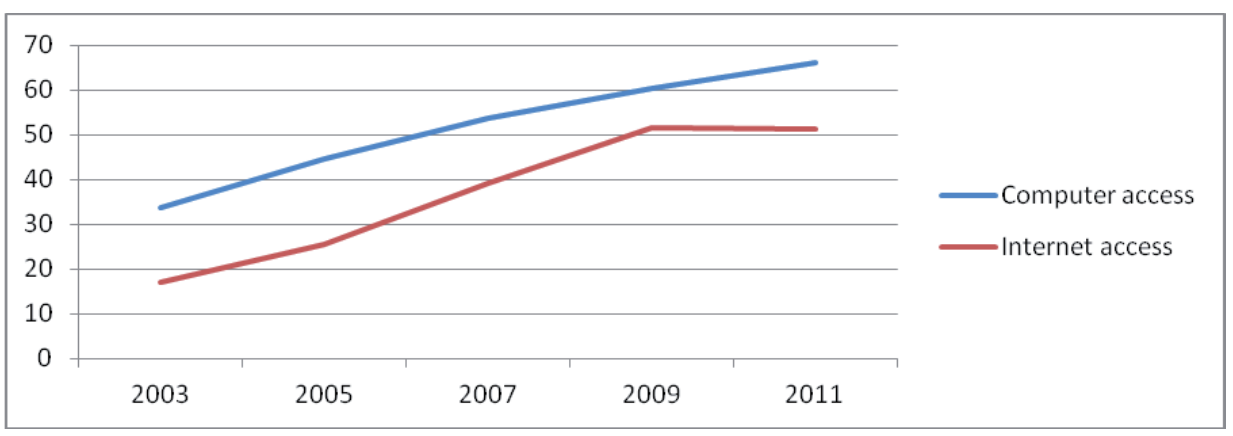

Figure 2. Household computer and Internet access in Poland in years 2003 - 2011 (\% data)

Source: Batorski, 2011, p. 299.

As we can see, shortly before joining the EU less than $20 \%$ of Polish households declared access to the Internet. At present the scale of the digital divide is much smaller, but this problem still exists. In 2011, nearly half of polish households do not have Internet access. According to experts, digital exclusion could be one of the biggest problems of the modern world (van Dijk, 2010). There is still a high level of digital exclusion in Poland.

It is difficult to talk about polish e-government in isolation from the European Union context. The development of electronic solutions implemented by the polish government is closely associated with the integration processes. Before access to the EU, Poland had to fulfill a number of varied conditions. Some of them were related to implementation of e-government solutions (Doktorowicz, 2005).

Firstly, the Public Information Bulletin (BIP) was introduced. It is a unified system of web pages, designed to make public information available for the general public. The Public Information Bulletin (BIP) was created for public access to the public information in digital form. The Bulletin consists of web sites on which public authorities and other entities performing public functions provide public information required by Polish law (www.bip.gov.pl).

In 2002, the concept of Wrota Polski (Polish Gateway) was presented. It was created to make an integrated information system, enabling provision of public services via the Internet, and in a broader sense, to open the country for new techniques and cooperation with other countries in this area. The continuation of the Wrota Polski is the e-PUAP project (Electronic Platform of Public Administration Services). It is actually based on the same assumptions (J. Papińska-Kacperek, 2008, p. 538). However, during the implementation, it turned out, that not everything was 
correct. In 2009 the report of the Najwyższa Izba Kontroli (Supreme Chamber of Control) evaluated the implementation of the e-PUAP and STAP project (Public Administration Network) very critically. The lack of progress in the implementation of STAP, and also many shortcomings in the implementation of e-PUAP, including incomplete functionality and a number of errors that had blocked its operation, were noted. Overall rating indicated the lack of significant progress in the development of e-government structures (Grodzka, 2009, p.75).

The most popular e-services in Poland, according to e-offices, are connected with economic activity of citizens, like company registration (www.egov.pl). Figure 3 shows the percentage of the most popular (according the offices) electronic services in 2011:

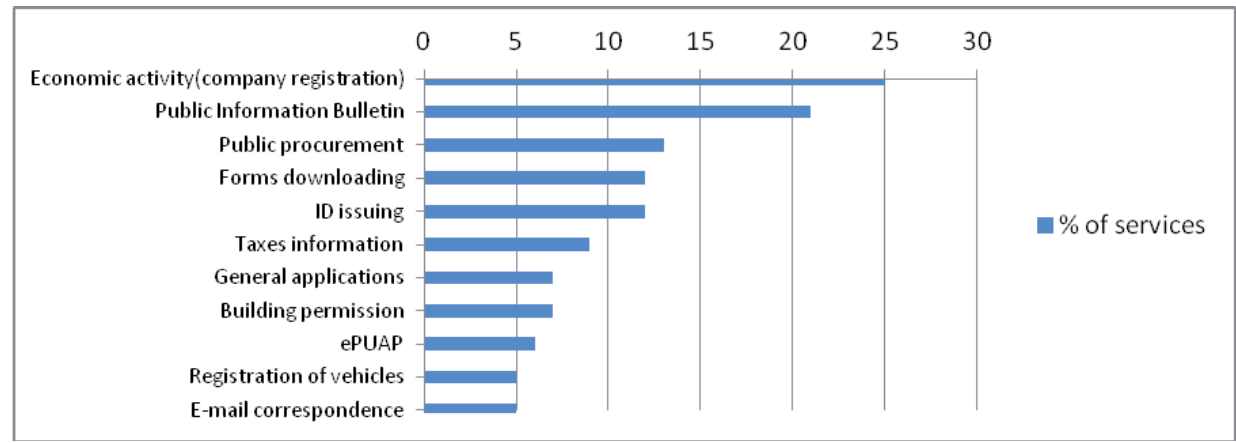

Figure 3. The most popular e-services in Poland in 2011

Source: www.egov.pl

As we can see, generally, the interest in e-services is relatively small. This may be associated with soft barriers (connected with citizens) of e-government development, lack of knowledge about the opportunities offered by e-government, low level of e-skills or lack of confidence in e-offices. All of this can create low interest in the new forms of administration (Kasprzyk 2011, pp. 347-348).

\section{SPECIFICS OF POLISH E-GOVERNMENT}

In Poland, for the past several years various units were responsible for digitalization, and development of electronic government. Firstly, it was a task of the Ministry of Internal Affairs and Administration (MSWiA). In 2011, as a result of the partition of MSWiA the Ministry of Administration and Digitization (MAC) was created. This ministry has to deal with issues related to the computerization of public administration. It is also connected with the implementation of the international obligations, in the field of information technology, with which Poland must comply. Most of them are connected with digitalization, and extension of the information society (mac.gov.pl).

The level of development of various structures of the information society is monitored regularly by many institutions and organizations. The stage of e-government is an important component of many statements evaluating the deve- 
lopment of the information society in the country. In the E-government Survey, a UN report published periodically, various factors are evaluated, such as willingness of states to implement innovative solutions in the field of e-Government (http://technologia.dziennik.pl/hitech/artykuly/381924,raport-onz-polska-eadministracja-jest-zacofana.html).

In the E-Government Survey 2012, published in 2012, Poland took the 47th place in the ranking of the world's e-government development index. The study has assessed 190 countries all over the world. Poland ranked below such countries as Kazakhstan, Slovenia, Croatia or Hungary (http:/ / www2.unpan.org/ egovkb/ global_reports/12report.htm).

In 2012 the European Commission stopped the payments of funds for e-government development in Poland. The reason for this decision was the fact, that during the implementation of projects some failures were detected. In April, the European Commission decided to discontinue the payments to Polish e-government projects because of concerns about the legality and regularity of expenditure and low efficiency of EU funding management (http:/ / www.tvn24.pl/wiadomosci-z-kraju,3/elektroniczna-administracja-w-polsce-wielki-wstyd,207830.html).

\section{CONCLUSION}

The state of development of Polish e-government is still not satisfactory. As we can see from the reports of E-government Survey other countries in Central Europe are developing better in this regard. The most worrying issues are various improprieties in the implementation of e-government. Particularly when it comes to corruption or problems with the use of funds from the EU. Moreover, we can suppose that so far the Polish authorities have not really seemed to realize how important the development of the information society structures is. But for the pressure from the EU, e-government would probably have been even worse than it is now. If this does not change in the future, the Polish position in the rankings of e-government may be even worse.

Also, an extremely important role in the implementation of e-government is an appropriate and a large-scale education of the public. Many people do not know that, thanks to modern facilities, they could do many things without leaving their home thanks to modern facilities. Many people are not aware of advantages which e-government brings. It is also very important to fight against the digital divide and to improve infrastructure. Without this, all the implementation of e-government becomes meaningless. Most important is the fact of operating these electronic offices efficiently and correctly, to comply with its tasks, such as saving time and money, making life easier for citizens and officials and changing the nature of the government for the better.

\section{REFERENCES}

Castells M., (2007), Społeczeństwo sieci, Warszawa, PWN.

Grodzka D, (2009), Elektroniczna administracja, in: „Społeczeństwo informacyjne”, D. Grodzka (red.), Warszawa, WSKS. 
Batorski D., (2011), Korzystanie z technologii informacyjno-komunikacyjnych, in: „Diagnoza społeczna 2011", Czapiński J., Panek T., (red.), Warszawa.

Dijk J., (2010), Społeczne aspekty nowych mediów, Warszawa, PWN.

Doktorowicz, K., (2005) Europejski model społeczeństwa informacyjnego, Katowice, Wyd. UŚ.

Kasprzyk B., (2011), Aspekty funkcjonowania e-administracji dla jakości życia obywateli, in: „Nierówności społeczne a wzrost gosporarczy", C.F. Hales (red.), Rzeszów , Wyd. URz.

Masłyk T., (2010), Obywatel w społeczeństwie informacyjnym, Kraków, NOMOS.

Społeczeństwo informacyjne, (2008), J. Papińska - Kacperek (red.), Warszawa, PWN.

\author{
Netography \\ www.unpan.org \\ www.bip.gov.pl \\ www.eadministracja.pl \\ www.egov.pl \\ www.mac.gov.pl \\ www.technologia.dziennik.pl \\ www.tvn24.pl
}

